\title{
Collaboration between Chiefs and Local Government Actors in Combating Climate Change: Evidence from New Juaben, Ghana
}

\author{
Kwabena Boateng and Reuben Tete Larbi
}

\begin{abstract}
Institutional barriers remain a constraint to efficient adaptation to climate change in many countries. Therefore, there is much to be desired regarding knowledge on the capacity and roles of local institutions in responding to climate change across sectors and locales. Drawing evidence from randomly selected chiefs and local government actors, and purposively selected officials of the Municipal Assembly, we examined how partnership between local government actors and informal institutions such as chieftaincy could enhance coordinated and integrated climate action and adaptation planning in local communities. All interviews were transcribed and analysed in themes generated from deductive codes. Participants demonstrated varied levels of knowledge on the causes and impacts of climate change. We observed the implementation of several unstructured climate change activities in local communities as actors of the two institutions individually and collaboratively implemented some adaptation and mitigation actions. We therefore conclude that when given the right attention, by addressing the problems which include financial allocation, low capacity of personnel, and the lack of coordination between units that confront the local institutions, informal institutions and local government actors, could spearhead lasting climate change adaptation and mitigation programmes, and produce equity and sustainability at the national level.
\end{abstract}

Keywords: Climate Change, Mitigation, Adaptation, Chiefs, Local Government Actors

\section{Résumé}

Les barrières institutionnelles continuent d' entraver une adaptation efficace au changement climatique dans de nombreux pays. En conséquence, il y a beaucoup à désirer, quant aux connaissances sur la capacité et les rôles des institutions locales dans la réponse au changement climatique à travers les secteurs et les localités. En nous appuyant sur les témoignages de chefs et d'acteurs des collectivité territoriales sélectionnés au hasard et de fonctionnaires de l'assemblée municipale sélectionnés à dessein, nous avons examiné comment le partenariat entre les acteurs des collectivités territoriales et les institutions informelles telles que la chefferie pourrait améliorer la planification coordonnée et intégrée de l'action et de l'adaptation climatiques dans les communautés locales. Nous avons transcrit et analysé tous les entretiens selon les thèmes générés par les codes déductifs. Les participants ont démontré des niveaux de connaissance variés, en ce qui concerne les causes et les impacts du changement climatique. Nous avons observé la mise en œuvre de plusieurs activités non structurées relatives au changement climatique dans les communautés locales, les acteurs des deux institutions ayant mis en œuvre individuellement et en collaboration certaines actions d'adaptation et d'atténuation. Ainsi, nous concluons que si l'on leur accordait la bonne attention en s'attaquant aux problèmes tels que l'allocation financière, la faible capacité du personnel, et le manque de coordination entre les unités auxquels sont confrontés les institutions locales, les institutions informelles et les acteurs des collectivités territoriales pourraient être le fer de lance de programmes durables d'adaptation et d'atténuation du changement climatique et pourraient produire

Mots-clés: changement climatique, atténuation, adaptation, chefs, acteurs des collectivités territoriales I'équité et la durabilité au niveau national.

https://dx.doi.org/10.4314/contjas.v8i2.3

Kwabena Boateng (sekyerehene2002@gmail.com) is a Sociology Lecturer at the Department of Social Sciences at Central University, Accra, Ghana. He was a visiting scholar at University of Southern Indiana as a doctoral student. His research interests include chieftaincy and traditional leadership, conflict studies, community/rural development, local government, climate change, and environmental sustainability.

Reuben Tete Larbi (reuben.tete.|@gmail.com) is a Postdoctoral Research Associate at the Lancaster Environment Centre, Lancaster University, UK. He has a demonstrated experience in population and environment research, particularly in low-income urban communities. Reuben has a PhD in Population Studies from the University of Ghana and is an alumnus of the Fox International Fellowship at Yale University, USA. Reuben currently works on the UKRI funded RECIRCULATE project which seeks to build capacity for Africa's circular water economy. He has research interest in water, sanitation and health; sustainable livelihoods and urban poverty; resilient cities; and climate change adaptation 


\section{Introduction}

Institutional barriers remain a constraining factor to effective climate change adaptation in many countries (Bisaro et al., 2018; Mandryk et al., 2015; Biesbroek et al., 2013; Agrawal, 2010). Centralised capacity and resources that remain within the confines of the elites tend to create institutional traps that inhibit efficient climate action at the grassroot (Lebel et al., 2011). The need to direct attention to local causes and responses to climate change has gained much attention in recent times (Baker et al., 2012; Gupta et al., 2010). Some earlier scholars questioned the capacity of local administrations to effectively implement adaptation responses and rather concentrated their attention on the technical, economic resources, information, infrastructure and institutional capacity of central governments in combating climate change (Gemmer et al., 2011; Baker et al., 2012). There is, however, a growing recognition of the need for place-based programmes that enhance the capacity of local communities (Roggero, 2015). The role of governance, institutions and management practices, as precondition for implementing adaptation actions, is now highlighted (Mandryk et al., 2015). Much effort is therefore needed to develop the capacity of community-based or informal institutions for an enhanced climate action. One major avenue is concerted effort between formal/governmental actors and all stakeholders, including community leaders (Mason \& Fragkias, 2018; Glaas et al., 2010).

Ghanaian communities are characterised by an intricate co-existence of chieftaincy and local government actors within the same administrative areas (Sklar, 2003; Englebert, 2003; Odotei, 2003). Though chiefs and local government actors have different mandates, they play complementary roles in the development and sustainability of local communities. Traditionally, local governance was centred on chiefs who performed numerous roles such as custodians of natural resources and adjudication (Brempong, 2007; Boafo-Arthur, 2006; Rathbone, 2000) to support and promote the development of their communities. Under the decentralised system in Ghana, local governance does not include chiefs (Republic of Ghana, 2016; Taabazuing et al., 2012). District Assemblies have been established with executive, deliberative and legislative powers to manage communities under their jurisdictions (Republic of Ghana, 1992).

Although the establishment of the local government system reduced the visibility, powers and functions of chiefs, chieftaincy remains relevant in local administration of Ghanaian communities. Chiefs have become disseminators of governmental policies and programmes (Addulai, 2006; Seini, 2006). As custodians of natural resources including forests, several land-use practices which have implications of climate change mitigation and environmental sustainability remain in the domain of chiefs. The mandate of chiefs and local government actors allows them to implement activities and projects that increase or reduce Greenhouse Gas (GHG) emissions.

The United Nations Framework Convention on Climate Change (UNFCCC) attributes anthropogenic climate change directly or indirectly to human activity that alters the composition of the global atmosphere through the emission of $\mathrm{GHG}^{1}$. The convention requires a concerted international action to mitigate climate change and to adapt to its impacts (UNFCCC, 2006). Ghana has committed itself to the UNFCCC's agenda of pursuing low carbon emissions and has put forward twenty mitigations and eleven adaptation programme actions in the Nationally Determined Contributions (NDCs) submitted to the UNFCCC under the Paris Agreement (Government of Ghana [GoG], 2015a).

Though African countries produce less than 3\% of global GHG emissions, they bear a brunt of the impacts. The impacts result from climatic risks such as droughts, flooding, extreme heat, and storms. Exposure to these hazards causes both economic and non-economic losses, thereby affecting livelihoods, household assets, health, cultural heritage, mobility, and even human life when the limit to adaptation is reached or adaptive capacity is simply absent (Satterthwaite et al, 2021; Van der Geest \& Warner, 2020). Flooding in the cities has become a predominant natural hazard that accompanies Ghana's rapid urbanisation (Amoako, 2016). The implementation of the programme of actions is expected to result in effective adaptation in order to minimise these losses and also reduce GHG emission through sustainable land-use, integrated water resource management, climate-proof infrastructure, sustainable forest management, urban waste management, and equitable social development (GoG, 2015a). Given that climate change disproportionately affects the poor and vulnerable in developing countries (IPCC, 2014) the close contact of chiefs and local government actors with local communities make them key players in the implementation of adaptation programmes.

Despite the increasing responsibility on local government actors to respond to climate change via adaptation planning and implementation, research on the capacity of local institutions in responding to climate change remain scanty, leaving knowledge gaps in institutional roles and coordination across sectors and locales (Baker et al., 2012). Thus, contribution of these two actors in combating climate change and adapting to its impacts remains under-researched. Extant literature has focused on the role of chiefs in community development (Knierzinger, 2011; Bob-Milliar, 2009; Kuponiyi, 2008; Nugent, 1996), chieftaincy and natural

\footnotetext{
1 GHG present in the atmosphere absorb and emit radiation within the thermal infrared region, a process that is fundamental cause of global warming.
} 
resource management (Campion \& Acheampong, 2014; Bernard \& Kumalo, 2004), and the role of local government in community development and adaptation to climate change (Islam \& Nursey-Bray, 2017; Lebel et al., 2011; Nunkoo, 2015; Cuthill, 2002).

This paper, therefore, examined the co-existence and overlapping jurisdictions of chieftaincy and local government actors in implementing activities that reduce GHG or enhance adaptation in local communities. This study contributes to the knowledge gap by investigating the knowledge and collaboration between chiefs and local government actors in mitigation and adaptation to climate change. The paper is structured as follows: section on chieftaincy, local government and environmental sustainability. This is followed by sections on conceptualising institutions and climate change responses, and the conceptual framework of the study. The methodology section discussed the study design and research methods adopted in the study. The results and discussion section dealt with findings of the study followed by the conclusion and recommendation sections.

\section{Chieftaincy, Local Government and Environmental Sustainability}

In Ghana, the existence of the chieftaincy institution and traditional councils as established by customary laws is recognised in the 1992 constitution. A chief is defined as "a person who, hailing from the appropriate family and lineage has been validly nominated, elected and enstooled, enskinned or installed as a chief or queenmother in accordance with the requisite applicable customary law and usage" (Republic of Ghana, 1992, p.168). Chiefs are selected based on their genealogical connections to the founders of their communities by the queen, in collaboration with the kingmakers (Fayorsey, 2006). The stool or skin of a chief represents the office of the traditional leader (Osei, 2002). Chiefs, in collaboration with local government actors, manage communities under their jurisdiction. However, in areas where the presence of the central government is not visible, local governance rests solely on chiefs.

Currently, apart from considering the kinship ties of the prospective candidates, kingmakers also consider their educational achievements (Brempong, 2007; Akrong, 2006). The expectation of the kingmakers is that, highly educated chiefs would utilise their social networks to bring about socio-economic development in their traditional areas. This has led to the enstoolment and enskinment of many non-hereditary- both indigenes and expatriates as development chiefs (Brempong, 2007; Boafo-Arthur, 2006).

Chiefs act as managers in modern organisations (Abdulai, 2006). As managers, chiefs perform interpersonal, informational and decisional roles. The informational roles include being a figurehead of his community, a leader, as well as liaising with external bodies that are capable of providing developmental projects in the community. Chiefs in their interactions with external organisations woo investors by projecting the investment potentials of their traditional areas (Boateng et al., 2016; Abdulai, 2006).

The decisional managerial functions of chiefs include entrepreneurial, dispute resolution, negotiating on behalf of their communities and resource allocation (Abdulai, 2006). Resources allocation denotes the "manner in which an economy distributes its resources among the potential users, so as to produce a particular set of final goods" (Samuelson \& Nordhaus, 1992, p.746). Chiefs also allocate resources to indigenes and potential foreign investors. Chiefs and lineage heads ensure environmental sustainability of communal resources. They are expected to also ensure that the environment is not depleted as it belongs to the ancestors, current and future generations (Alhassan, 2006). Among the Dagombas in Ghana, natural economic resources such as shea butter and the dawadawa trees were controlled by chiefs (Seini, 2006; Boaten, 1994). Hence the growth or depletion of these perennial trees, to a large extent, depends on how chiefs manage them, that is, regulating their use by their subjects.

Local government is defined as an institution that represents the microscopic interests of a locality, leading to the broader concept of welfare and happiness of its people (Sikander, 2016). The concept is also defined as a legally composed institution or organisation that ensures that people within a specific territorial enclave act collectively to ensure their welfare (Ndreu, 2016). Local government consists of functions performed by local authorities (Ahwoi, 2017). Local government is therefore the exercise of authority at the community level, with vested powers which the central government cedes to local government entities to provide some social services such as street lighting, education, health, roads and other infrastructure.

Local governance happens when people live in community, interact and collaborate to purposefully achieve common goals. The basic elements of local government are the management of public services and enabling citizens to participate in governance and development. Local government thus enables members within a locality to manage their own affairs. For the purposes of local government, Ghana divided its territory into districts, with Parliament tasked to enact laws that will ensure that functions, powers, responsibilities and resources are transferred from the Central Government to local government units (Republic of Ghana, 1992). 


\section{Conceptualising Institutions and $\mathrm{Cl}$ imate Change Response}

Institutions represent collective practices of formal (regulations, agreements, laws, conventions and property rights) and informal (customs, codes of conduct and traditions) through which individuals achieve common societal goals (Bisaro et al., 2018; Mandryk et al., 2015). North (1991) posits that these institutions are fashioned to constrain individuals for the purposes of maximising the wealth or utility of the principals. These different framing of institutions depicts its complexity, yet centrality, to organisational function including climate action. Institutional mechanisms such as rules on allocation of resources can positively or negatively affect implementation of programme actions and decision-making process by local government actors (Bisaro et al., 2018; Theesfeld et al., 2010). Whereas prompt and equitable distribution of resources is critical to advancing adaptation, centralised resources tend to cripple planning and programme implementation at the local level (Lebel et al., 2011). Institutions that support proactive response by social actors enhance the overall adaptive capacity of communities (IPCC, 2007). Gupta et al. (2010) identifies qualities that enhance adaptation to climate change to include fair governance, learning capacity, and access to resources.

Within the climate change adaptation literature, institutions have been framed by the domains of structure and function. While the structural domain focuses on the framework of operations such as decentralisation for meeting the needs of local communities, the functional domain encompasses the role of institutions and institutional arrangements in enhancing adaptation at the local level (Adger, 2003; Lebel et al., 2011). The structural institutional framework could consist of both formal and informal structures that co-exist within overlapping jurisdictions and have varying levels of power (Mubaya \& Mafongoya, 2017). Such linked structural framework could improve public participation in designing and implementing climate change programmes, as well as building capacities at multiple levels, which could yield localised capacity for adaptation and mitigation strategies (Mason \& Fragkias, 2018; Islam \& Nursey-Bray, 2017). An integration of these two domains of institutions provided an analytical framework for our study.

\section{Conceptual Framework}

Mixed government was adopted to examine the collaboration between chiefs and local government actors in combating climate change. The theory considers the co-existence of modern and traditional political structures (Sklar, 2003; Englebert, 2003). Prior to the contacts with European merchants, chiefs administered their territorial boundaries with the assistance of their council of elders. Economic and other activities in the various communities revolved around chiefs. Chiefs acted as the intermediaries between the living and the dead, and utilised religio-cultural practices in managing communal properties. These resources which included lands, river bodies and other natural resources on which members of the community largely depended on. The notion that communal property belonged to the ancestors and future generations as well as the role of the ancestors in ensuring that members conformed to rules and regulations was entrenched within this epoch.

Traditional political systems were transformed with the advent of colonial rule. In British colonies in Africa, colonial administration coopted chiefs in the administration of the colonies in a governmental system referred to as indirect rule (Brempong, 2007; Blanton et al., 2001; Rathbone, 2000). Chiefs under this system were tasked to perform some functions under the Native Authorities created for the purpose of local governance (Ahwoi, 2017; Mahama, 2009; Rathbone, 2000). Financial constrictions on the part of the colonial authorities deterred them from fashioning an administrative machinery based on the Westminster model as was practiced in the metropolis. The colonial administrators were thus inclined to utilise the services of a wellfunctioning as well as tried and tested indigenous political administration to achieve the materialisation of the colonial mandate. Native Authorities established during the colonial era undermined the powers of chiefs-making them appendages of the colonial regime (Mahama, 2009) and also antagonised the relationship between the indigenes, especially between the emerging African political elites and chiefs.

This notwithstanding, post-colonial governments throughout Africa created political structures based on traditional political institutions. The strong executive arm of government bequeathed to post-colonial African nations coupled with the antagonised relationship between chiefs and the indigenous political elites led to the reduction of the powers and functions of chiefs. Within this political arrangement, modern structures occupy the first dimension of the political hierarchy while traditional political institutions fall behind the former (Sklar, 2003). Political officials in modern government structures derive their legitimacy from constitutional provisions, while traditional political holders derive legitimacy from customs and traditions passed on from generation to generation (Brempong, 2007; Sklar, 2003). The levels of incorporation of traditional structures in governance vary considerably from country to country. Francophone countries have higher levels of incorporation than British colonies (Sklar, 2003). In former British colonies, chiefs have constituted advisory organs for modern political holders or serve as ex-officio members of local government structures.

In Ghana, the National and Regional Houses of Chiefs have been established to advise political officials on matters relating to chieftaincy (Republic of Ghana, 1992). The Constitution also allows qualified chiefs to be members of some National Authorities. The President of National House of Chiefs for instance, is a member of 
the Council of State. A representative of the National House of Chiefs serves on the Prison Council and Lands Commission. In addition, the Regional Houses of Chiefs have representatives on their respective Regional Coordinating Councils (Brempong, 2007; Republic of Ghana, 1992).

At the local level, chiefs co-exist with local government structures. A District Assembly is composed of a District Chief Executive, one person from each electoral area elected based on universal adult suffrage, a member or members of Parliament within the jurisdiction of Assembly, and other members that shall not exceed thirty percent of the total membership of the District Assembly appointed by the President (Republic of Ghana, 1992, 2016). The latter are appointed in consultation with interest groups and with chiefs. District Assemblies perform multiplicity of functions. Some of the functions include exercising political and administrative authority in the district, promoting local economic development, provision of guidance and supervision of administrative authorities in the district, preservation of the cultural heritage in the district, sponsoring the education of students in the district to improve on the human resource capacity in the district, among others (Republic of Ghana, 1992, 2016).

Due to social change, the functions of chiefs are categorised into statutory and non-statutory functions (Brempong, 2007). Statutory functions are those enshrined in the 1992 Constitution and the Chieftaincy Act, 2008 (Act 75) for chiefs to perform. Some of these functions include progressively studying, interpreting and codifying customary laws, compiling customary laws and lines of succession applicable to stools and skins in the country, among others (Republic of Ghana, 1992). Non-statutory functions on the other hand are functions chiefs have historically performed but have been transformed by factors of social change. These include conflict resolution and organisation of festivals used to promote cultural tourism (Boateng \& Bawole, 2021; Boateng \& Afranie, 2020; Brempong, 2007). As agents of community development, chiefs lobby government officials and other development partners for projects aimed at alleviating poverty and marginalisation at the countryside. Chiefs serve as intermediaries between the ancestors and the living generations. As such, they supervise the performance of periodic sacrifices to elicit the support and benevolence of the ancestors who oversee the affairs of members of the society. Though the relationship between modern and traditional political structures are characterised by conflicts at times, the two actors collaborate in diverse ways to promote community development. It is within this framework that the collaboration between chiefs and local government actors in combating climate change is analysed. 


\section{Methodology \\ Study Area}

The study was conducted in the New Juaben Municipal Assembly (NJMA) located in the Eastern Region, Ghana. The Assembly covers a land area of 110 square kilometers stretching from Suhyen to Okroase to Aboabo and to Akwadum (GSS, 2014; Ayakwah \& Mohammed, 2014). The municipality has a population of One Hundred and Eighty-three Thousand, Seven Hundred and Twenty-seven (183,727) [GSS, 2014]. The people of New Juaben are part of the Akan ethnic group and constitute about $56.9 \%$ of the population. Other ethnic groups in the municipality include the Ga-Dangme, Ewe, Guan, Gurma, Mole Dagbon, Grusi and Mande (GSS, 2013).

Koforidua, the capital of NJMA is the seat of the paramount chief for the New Juaben Traditional Area (NJTA). The Municipal Chief Executive, an appointee of the President is the head of the municipality (Republic of Ghana, 1992). Each electoral area is represented by an Assembly member, who is assisted by Unit Committee members. The municipality is endowed with forest resources and water bodies like the River Densu. Crops cultivated in the study area include cocoa, plantain, cassava and vegetables. Flooding and occasional landslides have become major environment problems in the municipality, causing loss of assets, displacements and livelihood disruptions. Informed by the above environmental challenges, the researchers selected the study area to ascertain how chiefs and local government authorities collaborate to combat climate change. Below is the map of the study area.

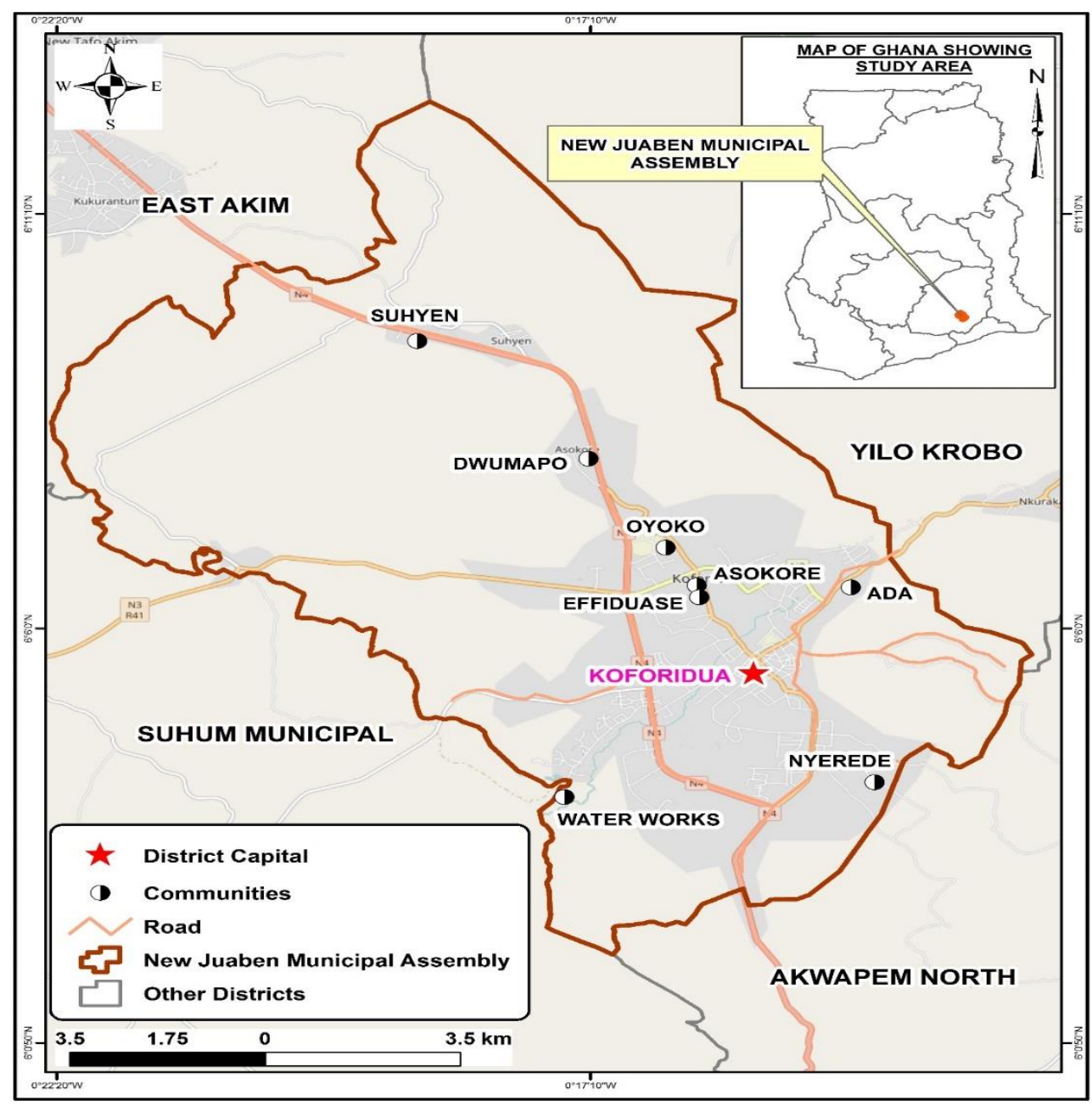

\section{Data and Methods}

The research questions informed the adoption of qualitative approach for the study. Twenty-one participants selected for the study were composed of one female and twenty males. Though the approach favoured the utilisation of smaller numbers, the intense interaction between researchers and participants provided valuable data and insight into the problem under investigation. Participants consisted of nine chiefs, nine local government actors/Assembly members and three Assembly officials. Five communities, out of the eight in the traditional area, namely Suhyen, Asokore, Jumapo, Koforidua and Effiduase were selected through simple random sampling. Divisional chiefs in these communities and the Assembly member in Suhyen were purposively selected for the study. In the other communities with more than one Assembly member, simple random sampling was used to select a person for the study. Principal officials in the Assembly from the Planning Unit, Environmental Office and the Environmental Protection Agency (EPA) were purposively selected due to their unique roles in environmental sustainability. 
The semi-structured interview enabled the exploration of 'local surprises' which we may not have been considered during the formulation of the research questions. Chiefs and local government actors were contacted through telephone to schedule interview sessions. Prior to the interviews, the objectives of the research were explained to participants and confidentiality was assured (Creswell, 2014). Interviews were mainly conducted in English; a few chiefs were interviewed in Twi and each session lasted between forty to forty-five minutes. Interviews were transcribed, translated where necessary and managed with NVivo 11. Both inductive and deductive codes were developed after reading the transcripts thoroughly. Deductive codes were developed from our research questions, while the inductive codes emerged from the narratives. Major themes identified were knowledge of climate change, adaptation and mitigation activities, expected roles of the central government, and challenges in combating climate change. We ensured rigor and credibility of results through peer review of transcripts, matching field notes and independent analysis by authors.

Table 1: Demography of Participants, Sampling Techniques and Major Questions Asked

\begin{tabular}{|c|c|c|c|c|}
\hline Category & No & Reason for selection & $\begin{array}{l}\text { Sampling } \\
\text { Technique } \\
\text { Adopted }\end{array}$ & Major Questions Asked \\
\hline $\begin{array}{l}\text { Local government } \\
\text { officials }\end{array}$ & 3 & $\begin{array}{l}\text { Tasked to plan the } \\
\text { municipality }\end{array}$ & Purposive & $\begin{array}{l}\text { - What are the causes of } \\
\text { climate change and } \\
\text { what impacts do local } \\
\text { communities } \\
\text { experience? } \\
\text { - What are some mitigation } \\
\text { and adaptation strategies } \\
\text { you have implemented or } \\
\text { seek to implement? } \\
\text { Is there collaboration } \\
\text { between chiefs and local } \\
\text { government actors in } \\
\text { combating climate } \\
\text { change? } \\
\text { What are some of the } \\
\text { challenges you encounter } \\
\text { in implementing policies } \\
\text { aimed at combating } \\
\text { climate change? }\end{array}$ \\
\hline
\end{tabular}




\begin{tabular}{|c|c|c|c|c|}
\hline Chiefs & 9 & $\begin{array}{l}\text { Custodians and } \\
\text { managers of } \\
\text { communal } \\
\text { resources. }\end{array}$ & Purposive & $\begin{array}{l}\text { - What are the causes of } \\
\text { climate change and } \\
\text { what impacts do local } \\
\text { communities } \\
\text { experience? } \\
\text { - What are the traditional } \\
\text { methods of conserving } \\
\text { the environment? } \\
\text { - What are some mitigation } \\
\text { and adaptation strategies } \\
\text { you have implemented or } \\
\text { seek to implement? } \\
\text { Is there collaboration } \\
\text { between chiefs and local } \\
\text { government actors in } \\
\text { combating climate } \\
\text { change? }\end{array}$ \\
\hline Assembly members & 9 & $\begin{array}{l}\text { Representatives of } \\
\text { the people in the } \\
\text { District Assembly }\end{array}$ & $\begin{array}{l}\text { Simple random \& } \\
\text { Purposive }\end{array}$ & $\begin{array}{l}\text { - What are the causes of } \\
\text { climate change and } \\
\text { what impacts do local } \\
\text { communities } \\
\text { experience? } \\
\text { - What are some mitigation } \\
\text { and adaptation strategies } \\
\text { you have implemented or } \\
\text { seek to implement? } \\
\text { - Is there collaboration } \\
\text { between chiefs and local } \\
\text { government actors in } \\
\text { combating climate } \\
\text { change? } \\
\text { Does the Assembly } \\
\text { collaborate with you } \\
\text { on climate change } \\
\text { policy formulation and } \\
\text { implementation? }\end{array}$ \\
\hline Total & 21 & & & \\
\hline
\end{tabular}

Source: Authors' construct (2018) 


\section{Results and Discussion}

The results depict the existence of a mixed government in which chiefs and local government actors collaborated in combating climate change.

\section{Knowledge of Climate Change}

Participants conceived climate change as a change in the weather conditions of place. Increase in temperature was attributed to the emission of GHGs like carbon dioxide and nitrogen oxide through human activities. Climate

change was also associated with natural and anthropogenic processes. Some participants mentioned drought, perennial floods, land degradation and erratic rainfalls as some of the negative impacts of climate change. Though some participants had not experienced droughts in their communities, erratic rainfalls, flooding and landslide were familiar experiences. The depth of knowledge of climate change significantly differed among the chiefs, local government actors and officials from the Assembly. While the latter category gave explanation of the causes and impacts of climate change that were consistent of scientific explanations, some of the chiefs (4 of 9 ) and local government actors ( 5 of 9 ) accurately explained the causes and impacts of climate change. A chief remarked that:

As for climate change, it is everywhere; today it rains in the dry season. When you expect the rains, there is none. The raining seasons are not consistent any longer; it's difficult to predict when the rains will come (Chief, NJTA).

Another chief indicated that:

They always talk about climate change that the world is changing. We have been hearing about it in the news but these things only God knows. Only God knows how the world will end (Chief, NJTA).

\section{Adaptation and Mitigation Activities of Chiefs and local government actors}

The programmes and activities undertaken by chiefs and the local government in response to climate change and its impacts are classified under adaptation and mitigation measures.

\section{Mitigation Measures}

Mitigating measures are principally aimed at reducing the emission of greenhouse gases into the atmosphere. Mitigation is anchored on the notion that the accumulation of GHG (carbon dioxide) into the atmosphere must not only be reduced but stored in natural Carbon sinks like forest reserves to contain the depletion of the ozone layer. Carbon sequestration as a mitigation measure is considered an inexpensive mechanism for addressing climate change. The data showed that chiefs and local government actors independently or collaboratively implemented programmes and activities which had climate change mitigation effects but had not been implemented as climate change projects in most cases. Participants indicated that in communities where conflict characterised the relationship between chiefs and local government actors, programmes and activities on climate change were undertaken independently. Conflicts between the two actors were caused by the failure of local government actors to extend normal protocols and courtesies to chiefs, the lack of institutional representation for chiefs in local government structures and resource allocations (Ayee, 2007). A participant opined: 
When there are conflicts between local government actors and chiefs, this affects the process of collaboration between us. So, when we want to plant trees, such activities cannot commence because the chiefs as custodians of communal property, control lands in the community. So, for us to win this fight against environmental degradation, we have to be united in this course (IDI, 7).

Table 2: Climate Change, Mitigation Activities and Programmes.

\begin{tabular}{|c|c|c|}
\hline Programmes/Activities & Description & Sample quotes \\
\hline Forest management & $\begin{array}{l}\text { EPA officials and assembly } \\
\text { members on various occasions } \\
\text { engaged in tree planting } \\
\text { exercises }\end{array}$ & $\begin{array}{l}\text { We collaborate with chiefs in the } \\
\text { management of the environment [forest]. } \\
\text { As you know, chiefs are the custodians of } \\
\text { the land. So, for us to do anything in a } \\
\text { community pertaining to the land and the } \\
\text { forest, we need to collaborate with them. } \\
\text { During festive occasions, we plant trees } \\
\text { together with chiefs and officials of the } \\
\text { Parks and Gardens department. (Assembly } \\
\text { member, NJMA) }\end{array}$ \\
\hline & $\begin{array}{l}\text { Curtailing indiscriminate felling } \\
\text { of trees }\end{array}$ & $\begin{array}{l}\text { We have managed to minimise the } \\
\text { indiscriminate cutting of trees around this } \\
\text { area. The demand for wood is high due to } \\
\text { the increased infrastructural development } \\
\text { and charcoal burning for fuel wood. Those } \\
\text { who are caught are brought to book to deter } \\
\text { others (Chief, NJTA) }\end{array}$ \\
\hline Community sensitisation & $\begin{array}{l}\text { Sensitisation by chiefs, local } \\
\text { government actors, and EPA } \\
\text { officials on forest } \\
\text { conservation }\end{array}$ & $\begin{array}{l}\text { On the World Environment Day, we } \\
\text { periodically organise community durbars } \\
\text { and sensitise people on the need to } \\
\text { conserve the environment (EPA official, } \\
\text { Koforidua). }\end{array}$ \\
\hline Tree planting exercises & $\begin{array}{l}\text { Planting of trees for its } \\
\text { aesthetic value and } \\
\text { environmental conservation. }\end{array}$ & $\begin{array}{l}\text { We collaborate with chiefs to plant trees } \\
\text { during the main festival that is celebrated in } \\
\text { this town (Assembly member, NJMA). }\end{array}$ \\
\hline
\end{tabular}

\section{Source: Authors' construct (2018)}

The mitigation measures implemented in the communities include forest management, community sensitisation on environmental conservation, and tree planting (Table 2). Forest management activities included tree planting and curtailing indiscriminate felling of trees. Management of the forest by local government actors and chiefs was not solely to combat the risks of climate change, but also for other complementary benefits such as protection of the soil, conversation of biodiversity and other forest products. During the annual World Environment Day celebration, chiefs, local government actors, and officials from the EPA sensitised people on the need to conserve the environment. These officials also encouraged community members to plant trees and clean public places like markets and school parks.

Chiefs were instrumental in propagating government policies on environmental sustainability. Through meetings with government officials at both the National and Regional Houses of Chiefs meetings, chiefs familiarised themselves with governmental policies. At traditional durbars, chiefs relay information gained from external encounters to their subjects in their quest to enhance the materialisation of the objectives of the central government. Chiefs communicated complaints of members and local knowledge on environmental sustainability to local government officials for incorporation into national policy. Additionally, chiefs collaborated with local government actors during traditional festivals, National Sanitation Days, and other national holidays 
to plant trees (Table 2). These collaborations were useful because while local government actors had the material resources, chiefs had the strength to mobilise subjects and allocate land for projects. Forest management denotes the processes of planning and implementing strategies aimed at safeguarding the use of forests and wooded land to achieve specific environmental, economic and socio-cultural goals (Keenan et al., 2015). Most rural households use charcoal and firewood for cooking, and this demands felling of trees. Continuous use of these wood fuel coupled with rapid population expansion leads to the depletion of forest and removal of carbon sinks. In response to this and similar problems, the government of Ghana did a Technology Needs Assessments (TNA) in 2003 that focused on mitigation in the energy and waste sectors, and on adaptation in water and agricultural sectors in 2013. These exercises were to identify, select and prioritise technologies needed to mitigate and adapt to climate change (Government of Ghana, 2015b). The TNA led to the introduction of energy saving devices such as refrigerators and electric bulbs. Though these interventions have not been fully implemented in rural areas due to financial and logistical constraints, local government actors and chiefs have promoted these through public education.

In the traditional societies, chiefs demarcated sections of the community as sacred grooves and abodes of the ancestors. The fundamental orientation for the creation of these reserves, interwoven in the mystical doctrines of traditional religion, was to conserve them for posterity. However, population expansion and secularisation of traditional norms have eroded these practices leading to indiscriminate clearing of forests for diverse purposes. Despite the challenge that beset forest management, chiefs and local government actors have preserved the Koforidua Park for recreational purposes.

Also, the chiefs of Akwadum have established the Akwadum-Mpaem Forest. Though the AkwadumMpaem forest is not classified as a sacred grove, where libations are poured periodically, inhabitants are prohibited from farming, hunting or harvesting wood in the enclave. The creation of sacred groves and forest reserves were embodiments of traditional ecological strategies to conserve the environment. Chiefs utilised religious and political sanctions to safeguard the environment. The orientation that the ancestors have power to sanction individuals who mismanaged environmental resources served as a social control mechanism.

\section{Adaptation Measures}

The fundamental ethos of adaptation is to moderate the negative consequences of climate change and take advantage of any existing opportunities. Adaptation considers the changes that communities make to reduce the damage (or increase the benefit) of climate change (Mandelsohn, 2006). The data showed that chiefs collaborated with the Ministry of Food and Agriculture through its Extension Officers, to educate farmers on adaptation practices in response to drought. The chiefs mobilised the farmers for these capacity development programmes. A chief and farmer indicated:

Periodically, Extension officers from the Assembly organise training for us. Basically, these are

centered on the adoption of improved plantings/seedlings and the cultivation of good farming

practices. These farming practices do not only increase crop yield but also ensures that there are positive physiological impacts on crops and livestock (Chief, NJMA).

Through these training programmes, farmers were encouraged to use newly improved and drought resistant crops and use traditional farming practices such as mixed cropping and mulching to conserve soil nutrients and water. Other practices included construction of rain gutters to harvest water for domestic purposes, digging pits on farms to conserve water for farming and not to cultivate close to water bodies in order to conserve the vegetation around them.

In addition, the District Assembly constructed drains as an adaptation response to the perennial flooding and landslides in the municipality. Participants attributed the floods and landslides to inadequate drainage systems and indiscriminate dumping of refuse in the few drainages available. Chiefs, in collaboration with Assembly Members, conducted periodic clean up exercises and desilting of drainages. During the National Sanitation Days, the Municipal Assembly collaborated with chiefs and Assembly members to desilt clogged drains to prevent the risk of flooding during heavy downpour. Similar exercises were conducted on festive occasions such as the Akwasidae, a major traditional celebration which involves the purification and commemoration of the ancestors of the traditional state believed to inhabit the black stool.

Participants mentioned the construction of irrigation dams for farming and domestic use as an adaptation measure. These dams ensure annual agricultural activities irrespective of the season. In line with the government's policy to construct a dam in each district across the country, the Assembly in collaboration with some chiefs have demarcated tracts of lands for that purpose. The cost of construction in terms of materials and engineering knowledge are to be funded by the central government. A planning officer explained: The construction of irrigation dams is one of the adaptation measures against the impacts of climate change. The Assembly has collaborated with chiefs to get lands ready for this government's policy of constructing a dam in every district. We will hold a stakeholder meeting to map up strategies for the materialisation of this 
objective. When constructed, these dams will to a large extent, enhance food security as farmers will be able to produce their crops without the need to depend on rainfall (MPO, NJMA).

The construction of irrigation dams was conceived as adaptation measure and a response to outstanding developmental problems. In either case, given that climate change is a developmental problem highlights how its impacts can compound existing non-climatic stressors in local communities. Other adaptation measures participants mentioned include institutional capacity development, protecting natural resources, provision of financial assistance to combat GHG emission, as well as gender-sensitive development planning and awareness creation. The institutionalisation of gender-sensitive developmental planning and policy implementation in response to the climate change is essential, as females constitute about $51.7 \%$ of the population in NJMA. The female population is also involved in activities that have explicit and implicit impacts on the environment. They are engaged in agriculture and harvesting firewood for domestic and economical purposes. It is therefore prudent, to involve women in policy formulation, implementation and in decision-making process. A participant explained that:

Institutional capacity development is needed in the fight against climate change. All the institutions with environmental management functions, must be resourced and their capacity developed. Ironically, not much is being done in this regard in NJMA.

\section{Expected roles of the Central Government in Responding to $\mathrm{Cl}$ imate Change}

Local government structures in Ghana largely depend on the central government to finance its projects and activities. As signatories to the various protocols on climate change and environmental sustainability, and with the Assemblies and chiefs having to contend with financial constraints, it was vital for the researchers to find out the role of the government beyond policy formulation. Some participants indicated the integration of qualified chiefs into some governmental institutions like the EPA enable them to contribute effectively in national policy formulation and implementation. Whereas chiefs desired an integration of the House of Chiefs into national policy frameworks, local government actors expected the central government to facilitate the process of decentralisation and mainstreaming of mitigation and adaptation measures into sectorial and District Assemblies' policies. Other expected roles were data gathering on climate change impacts, best practices, and regulation of technical and developmental planning policies. Mainstreaming climate change into sectorial and District Assembly policies will ensure climate-smart development projects. An official of the EPA remarked that:

For the EPA and the Assemblies, we largely depend on the central government for policy direction on climate change and environmental sustainability and funds to implement on climate change response programmes. Although funds are not sufficient, through partnership with CSOs we are able to organise sensitisation campaigns periodically.

In addition, there are fragmented activities and programmes across the Assembly, government institutions, and Civil Society Organisations (CSOs). According to participants, the central government has the responsibility to coordinate these programmes to ensure efficient natural resource utilisation. Sectorial regulation of technical and developmental planning policies is imperative, as policies provide incentives for the implementation of proactive adaptation measures (Eriksen et al., 2015). Planned adaptation measures are easily implemented when backed by strong and coherent policy frameworks that empower institutions to ensure compliance (Ayers et al., 2014; Klein et al., 2007). This is further fortified by integrating existing adaptation practices of local communities into programme implementation (Agrawal \& Perrin, 2009).

\section{Challenges of local Government Actors and Chiefs in Combating Climate Change}

According to government officials, key challenges regarding the planning and implementation of adaptation and mitigation programmes include lack of financial resources, low capacity of personnel, weak institutional structures, lack of collaboration between institutions, and lack of scientific methods or logistics. Low financial allocation to District Assemblies and the EPA are exacerbated by delay in the release of funds from the central government, which constrains the implementation of auxiliary actions such as climate mitigation. This is because infrastructure, like roads, hospitals, and schools, becomes the focus of the limited financial resources for governments. A local government official indicated that:

Every government wants to implement projects that will win the next election. Often climate change adaptation and mitigation programmes do not fall in these categories so there is lack of funding. So, though climate change units exist in some ministries and sectors, they are heavily under-resourced with no logistics and technology to make the offices productive.

Despite the global shift towards the use of technology like climate models to predict extreme events and prepare in advance, local government actors have little aptitude for technology, which makes planned adaptation a difficult thing to do. Adaptation measures are thus reactive and autonomous in many instances. In a few instances, knowledge on the contribution of climate change on the frequency and intensity of 
environmental hazards was limited among local government actors. In Australia, Baker et al (2012) found that though local government actors knew the projected impacts of climate change, there was no effective planning in combating climate change due to their limited capacity to use the knowledge to develop action plans. In Nigeria, there was the absence of institutional structure at the state and local government levels to address climate change (Oladipo, 2010). Capacity development programmes should not be limited to local government actors, but extended to chiefs, the custodians of resources, who their extractions have implications on climate change.

Flooding is a major rapid onset climatic event attributed to increased rainfall intensity generally, and exacerbated by a myriad of factors including poor waste management. Environmental officials at the Assembly highlighted waste management as one of the major problems confronting them with regard to adaptation to periodic flooding. Lack of trucks to convey waste to designated points, the absence of recycling plant to process waste or even export waste, and the inability to periodically collect domestic waste, impede waste management. Some participants argued that rainwater carried domestic waste materials into drains and water bodies that flowed in the municipality- contributing to the periodic flooding. A participant indicated that:

Waste management is a huge challenge. There are not enough dustbins in the households and at vantage places in the municipality. Also, lack of trucks and other logistics has hindered prompt collection of waste. Some of the waste find themselves in rivers and drains, causing flooding.

Similarly, the inability of the Environmental and Sanitation Department of the Assembly to enforce environmental bylaws was highlighted as a major institutional challenge. Previously, Environmental Health Officers prosecuted culprits of unsanitary practices. Chiefs and local government actors denounced the politics associated with the celebration of the World Environment and National Sanitation Days. Some argued that commitment from government and NGOs should move from the rhetoric and politics of planting trees to nurturing them. Some Assembly members opined that members who were critical of officials of the Assembly were not only denied developmental projects but also logistics for conducting communal labour on National Sanitation Days. The above explains the social and political influences that create vulnerability and inequality in time and space, as well as the role of power and politics in climate change adaptation (Eriksen et al., 2015; Mimura et al., 2014).

Furthermore, one challenge that the study unearthed was the establishment of climate change programmes in diverse institutions within the district without effective coordination and with little or no collaboration. This resulted in the duplication of climate change programmes at the grassroots. An integrated and coordinated institutional system is necessary to translate policies into intended outcomes (Leck \& Roberts, 2015). In addition, the fragmented institutional programmes create room for minimal or no incorporation of local contexts into national planning programmes, thus, producing the recipe for maladaptation (Dovie, 2017). Evidently, the problems that impede the implementation of climate change programmes identified in this study are not unique to our study area. Several studies have reported similar barriers, categorised as political, institutional, attitudinal, financial or resources, communication and awareness (Eisenack et al., 2014; Biesbroek et al., 2011; Biesbroek et al., 2013; Adger et al., 2009). As noted by Chaudhury et al. (2016), Ghana's use of existing formal decentralised structures and financial structures relegates climate change adaptation and mitigation below other development priorities.

\section{Conclusion and Recommendation}

The paper investigated the collaboration between chiefs and local government actors in combating climate change. The study revealed the potential of informal governance actors such as chiefs to enhance coordinated and integrated climate action. The collaboration between the two stakeholders in combating climate change was successful as they were able to galvanise mass community participation especially during tree planting exercises, community sensitisation and forest management programmes, that they organised. We posit that an inclusive and multi-sector approach to climate change mitigation and adaptation that accommodates the inputs of chiefs could enhance lasting programme outcomes. This could consequently foster equity and sustainability at the national level. Building partnerships among chiefs and relevant government and non-governmental sectors, to institutionalise concrete decision-making structures could enhance the adaptive capacity of local communities. Notwithstanding, an integration of informal institutions and formalised governmental agencies have not been well-considered in policy and practice (Agrawal \& Perrin, 2009). We therefore argue that when given the right attention by addressing the challenges identified in this study, informal institutions and local government actors could contribute to the achievement of the NDCs and sustainable climate action. We therefore recommend an integration of the chiefs into the structures of the Assembly, which deals with climate change related issues such as the Natural Resources Conservation, Forestry and Game and Wildlife Department, and Agriculture Department. This will give chiefs the regularised mandate to contribute meaningfully to national development and climate action. 


\section{References}

Abdulai, A.I. (2006). The Ghanaian chief as a manager: Between tradition and modernity. In I. K. Odotei, \& A.K. Awedoba (Eds.), Chieftaincy in Ghana: Culture, Governance and Development (pp.565-585). Accra: SubSaharan Publishers.

Adger, W.N., Dessai, S., Goulden, M., Hulme, M., Lorenzoni, I., Nelson, D.R., Naess, L.Otto., Wolf, J., \& Wreford, A. (2009). Are there social limits to adaptation to climate change? Climatic Change 93, 335-354. https://doi:10.1007/s10584-008-9520-z

Adger, W. N. (2003). Social capital, collective action, and adaptation to climate change. Economic geography, 79 (4), 387-404. Retrieved from: https://www.crcresearch.org/files-crcresearch/File/adger_03.pdf

Agrawal, A. (2010). Local institutions and adaptation to climate change. Social dimensions of climate change: Equity and vulnerability in a warming world, 2, 173-178. Retrieved from:https://www.researchgate.net/publication/319909624_Strengthening_the_Role _of_Local_Institutions_in_Protecting_the_Environment_of_Mount_Lawu_Areas_for_Tour ism_Purposes/link/59c142fbaca272295a09a450/download

Agrawal, A., \& Perrin, N. (2009). Climate adaptation, local institutions and rural livelihoods. In W.N.Adger, I.Lorenzoni, \& K.O'Brain (Eds.) Adapting to climate change: thresholds, values, governance (pp.350367). Cambridge, UK: Cambridge University Press. http://www.muthar-almor.com/wpcontent/uploads/2013/01/Adopting-to-Climate-Change.pdf

Ahwoi, K. (2017). Local Government \& Decentralization in Ghana (2 ${ }^{\text {nd }}$ ed.). Accra North: Winmat Publishers Limited.

Akrong, A. (2006). Religion and Traditional leadership in Ghana. In I. K. Odotei, \& A.K. Awedoba (Eds.), Chieftaincy in Ghana: Culture, Governance and Development (pp. 193-212). Accra: Sub-Saharan Publishers.

Alhassan, O. (2006). Traditional authorities and sustainable Development: Chiefs and Resources management in Ghana. In I.K. Odotei, \& A.K Awedoba (Eds.), Chieftaincy in Ghana: Culture, Governance and Development (pp. 527-546). Accra: Sub-Saharan Publishers.

Amoako, C. (2016). Brutal presence or convenient absence: The role of the state in the politics of flooding in informal Accra, Ghana. Geoforum, 77, 5-16. https://doi: 10.1016/j.geoforum.2016.10.003

Ayakwah, A., \& Mohammed, J. (2014). Fuel price adjustments and growth of SMEs in the New Juaben Municipality, Ghana. International Journal of Small Business and Entrepreneurship Research, 2(3), 1323. http://www.eajournals.org/wp-content/uploads/Fuel-Price-Adjustments-and-Growth-of-SMEsin-the-New-Juaben-Municipality-Ghana1.pdf

Ayee, J. R. A (2007, July). Traditional leadership and local governance in Africa: The Ghanaian experience. Paper presented at the Fourth National Annual Local Government Conference, Southern Sun Elangeni, Durban.

Ayers, J. M., Huq, S., Faisal, A. M., \& Hussain, S. T. (2014). Mainstreaming climate change adaptation into development: a case study of Bangladesh. Wiley Interdisciplinary Reviews: Climate Change, 5(1), 37-51. https://doi: 10.1080/17565529.2014.977761

Baker, I., Peterson, A., Brown, G., \& McAlpine, C. (2012). Local government response to the impacts of climate change: An evaluation of local climate adaptation plans. Landscape and Urban Planning, 1072), 127136. https://doi:10.1016/j.landurbplan.2012.05.009

Bernard, P., \& Kumalo, S. (2004). Community-based natural resource management, traditional governance and spiritual ecology in southern Africa: The case of chiefs, diviners and spirit mediums. Rights, resources \& rural development: Community-based natural resource management in Southern Africa, 115-126. https://doi: https://doi.org/10.4324/9781849772433

Biesbroek, G. R., Klostermann, J. E., Termeer, C. J., \& Kabat, P. (2013). On the nature of barriers to climate change adaptation. Regional Environmental Change, 13(5), 1119-1129. https://doi:10.1007/s10113-0130421-y.

Biesbroek, R., Klostermann, J., Termeer, C., \& Kabat, P. (2011). Barriers to climate change adaptation in the Netherlands. Climate law, 2(2), 181-199. https://doi: 10.3233/CL-2011-033

Bisaro, A., Roggero, M., \& Villamayor-Tomas, S. (2018). Institutional Analysis in Climate Change Adaptation Research: A Systematic Literature Review. Ecological Economics, 151,34-43. https://doi:10.1016/j.ecolecon.2018.04.016 
Blanton, R., Mason, D. T., \& Brain, A. (2001). Colonial Style and Post-colonial Ethnic Conflict in Africa. Journal of Peace Research, 38(4), 473-489. https://pdfs.semanticscholar.org/3767/1bd0398b37b83a679cdaaa1b1a0a88e7d15b.pdf

Boafo-Arthur, K. (2006). Chieftaincy in Ghana: Challenges and prospects in the $21^{\text {st }}$ century. In I.K. Odotei, \& A.K. Awedoba (Eds.), Chieftaincy in Ghana: Culture, Governance and Development (pp. 145-168). Accra: Sub-Saharan Publishers.

Boaten, B. A. (1994). Chieftaincy in Ghana-An Overview. Legon: Institute of African Studies, University of Ghana. (Mimeo).

Boateng, K., \& Afranie, S. (2020). All Hands-on Deck: The Process and Activities of Collaboration between Chiefs and Local Government Authorities in Ghana. Ghana Journal of Development Studies, 17 (1), 92$113 \mathrm{http} / / / \mathrm{dx}$.doi.org/10.4314/gjds.v17i1.5

Boateng, K., Afranie, S., \& Amoah, S.K. (2016). Social mobilisation in the midst of social change: The Case of traditional authorities in Ghana. Journal of Educational and Social Research, 6 (2), 103-112. https;//doi:10.5901/jesr. 2016.v6n2p103

Boateng, K., \& Bawole, J.N. (2021). Are two heads better than one? Challenges and prospects of chiefs and local government collaborative community development in Ghana. Community Development, 1-19 https://doi.org/10.1080/15575330.2021.1923043

Bob-Milliar, G. M. (2009). Chieftaincy, Diaspora, and Development: The Institution of Nk suohene in Ghana. African Affairs, 108(433), 541-558. https://doi: 10.1093/afraf/adp045

Brempong, N. A. (2007). Transformation in Traditional Rule in Ghana, 1951-1996. Accra: Sedeco Publishing Limited.

Campion, B. B., \& Acheampong, E. (2014). The chieftaincy institution in Ghana: causers and arbitrators of conflicts in industrial jatropha investments. Sustainability, 6 (9), 6332-6350. https://doi:10.3390/su6096332

Chaudhury, A. S., Ventresca, M. J., Thornton, T. F., Helfgott, A., Sova, C., Baral, P., ... \& Ligthart, J. (2016). Emerging meta-organisations and adaptation to global climate change: Evidence from implementing adaptation in Nepal, Pakistan and Ghana. Global environmental change, 38, 243257.https://doi.org/10.1016/j.gloenvcha.2016.03.011

Creswell, J.W. (2014). Qualitative Enquiry and Research Design: Choosing Among Five Traditions (4 ${ }^{\text {th }}$ ed.). London: SAGE Publications.

Cuthill, M. (2002). Exploratory research: citizen participation, local government and sustainable development in Australia. Sustainable development, 102), 79-89. https:// doi:10.1002/sd.185

Dovie, D. B. (2017). A communication framework for climatic risk and enhanced green growth in the eastern coast of Ghana. Land Use Policy, 62, 326-336. https://doi: 10.1016/j.landusepol.2017.01.008

Eisenack, K., Moser, S. C., Hoffmann, E., Klein, R. J., Oberlack, C., Pechan, A., \& Termeer, C. J. (2014). Explaining and overcoming barriers to climate change adaptation. Nature Climate Change, 4(10), 867. htpps://doi:10.1038/nclimate2350

Englebert, P. (2003). Resurgent indigenous structures and the reconfiguration of power in Africa. In O. Vaughan (Ed.) Indigenous Political structures and Governance in Africa (pp. 26-59). Ibadan: Sefer Books Ltd.

Eriksen, S. H., Nightingale, A. J., \& Eakin, H. (2015). Reframing adaptation: The political nature of climate change adaptation. Global Environmental Change, 35, 523-533. https://doi.org/10.1016/j.gloenvcha.

Fayorsey, C. (2006). Gender, Culture and Governance: Ghanaian Queen mothers as Leaders in Development. In I.K. Odotei, \& A.K. Awedoba (Eds.) Chieftaincy in Ghana: Culture, Governance and Development (pp.651662). Accra: Sub-Saharan Publishers.

Gemmer, Marco, Wilkes, A., Vaucel, L. M. (2011). Governing climate change adaptation in the EU and China: an analysis of formal institutions. Adv. Clim. Change Res. 2 (1), 1-11. http://dx.doi.org/10.3724/sp.j.1248.2011.00001

Ghana Statistical Service (GSS). (2014). Population and housing census. Accra: Ghana Statistical Service.

Ghana Statistical Service. (2013). Population and housing census. Accra: Ghana Statistical Service, 2002.

Glaas, E., Jonsson, A., Hjerpe, M., Andersson-Skold, Y., (2010). Managing climate change vulnerabilities: formal institutions and knowledge use as determinants of adaptive capacity at the local level in Sweden. Local Environ. 15 (6), 525-539. http://dx.doi.org/10.1080/13549839.2010.487525. 
Government of Ghana (2015a). Nationally Intended Determined Contributions and Accompanying Explanatory Notes, Accra Ghana. Retrieved from https://www4.unfccc.int/sites/ndcstaging/PublishedDocuments/Ghana\%20First/GH_INDC_2392015.p df

Government of Ghana (2015b). Ghana's Third National Communication Report to the UNFCCC, Ghana. http://unfccc.int/resource/docs/natc/ghanc3.pdf

Gupta, J., Termeer, C., Klostermann, J., Meijerink, S., van den Brink, M., Jong, P., ... \& Bergsma, E. (2010). The adaptive capacity wheel: a method to assess the inherent characteristics of institutions to enable the adaptive capacity of society. Environmental Science \& Policy, 13(6), 459-471.https://doi.org/(...j.envsci.2010.05.006

Intergovernmental Panel on Climate Change (2014). Climate Change 2014-Impacts, Adaptation and Vulnerability: Regional Aspects. Cambridge University Press. https://doi.org/10.1017/CBO9781107415386

IPCC, 2007: Climate Change (2007). Impacts, Adaptation and Vulnerability. Contribution of Working Group II to the Fourth Assessment Report of the Intergovernmental Panel on Climate Change, M.L. Parry, O.F. Canziani, J.P. Palutikof, P.J. van der Linden and C.E. Hanson, Eds., Cambridge University Press, Cambridge, UK, 976pp. https://www.ipcc.ch/site/assets/uploads/2018/03/ar4-wg2-intro.pdf

Islam, M.T., \& Nursey-Bray, M. (2017). Adaptation to climate change in agriculture in Bangladesh: The role of formal institutions. Journal of Environmental Management, 200, 347-358. https://doi: 10.1016/j.jenvman.2017.05.092.

Keenan, R. J., Reams, G. A., Achard, F., de Freitas, J. V., Grainger, A., \& Lindquist, E. (2015). Dynamics of global forest area: Results from the FAO Global Forest Resources Assessment 2015. Forest Ecology and Management, 352, 9-20. http://dx.doi.org/10.1016/j.foreco.2015.06.014

Klein, R. J., Eriksen, S. E., Næss, L. O., Hammill, A., Tanner, T. M., Robledo, C., \& O’ Brien, K. L. (2007). Portfolio screening to support the mainstreaming of adaptation to climate change into development assistance. Climatic change, 84(1), 23-44.

Knierzinger, J. (2011). Chieftaincy and development in Ghana: From political intermediaries to neotraditional development brokers. Institut für Ethnologie und Afrikastudien, Johannes Gutenberg-Universität.

Kuponiyi, F. A. (2008). Community power structure: The role of local leaders in community development decision making in Ajaawa, Oyo State, Nigeria. The Anthropologist, 10 (4), 239-243. https://doi.org/10.1080/09720073.2008.11891056

Lebel, L., Manuta, J. B., \& Garden, P. (2011). Institutional traps and vulnerability to changes in climate and flood regimes in Thailand. Regional Environmental Change, 11(1), 45-58. https://doi.org/10.1007/s10113010-0118-4

Leck, H., \& Roberts, D. (2015). What lies beneath: understanding the invisible aspects of municipal climate change governance. Current Opinion in Environmental Sustainability, 13,61-67. htpps:// 10.1016/j.cosust.2015.02.004

Mahama, C. (2009). Local economic development and local government in Ghana: Navigating a viable path to reform. Journal of Local Government Studies, 1(1), 29-54.

Mandryk, M., Reidsma, P., Kartikasari, K., van Ittersum, M., \& Arts, B. (2015). Institutional constraints for adaptive capacity to climate change in Flevoland's agriculture. Environ. Sci. Policy 48, 147e162. http://dx.doi.org/10.1016/j.envsci.2015.01.001 on 2 $2^{\text {nd }}$ October 21, 2018

Mason, S. G., \& Fragkias, M. (2018). Metropolitan planning organizations and climate change action. Urban Climate, 25, 37-50. https://dx.doi.org/10.1016/j.uclim.2018.04.004

Mendelsohn, R. (2006). The Role of Markets and Governments in Helping Society Adapt to a Changing Climate. Climatic Change 78 (1), 203-215. https://link.springer.com/article/10.1007/s10584-006-9088-4

Mimura, N., Pulwarty, R. S., Duc, D. M., Elshinnawy, I., Redsteer, M. H., Huang, H. Q., ... \& Sanchez Rodriguez, R. A. (2014). Adaptation planning and implementation 'Climate Change 2014: Impacts, Adaptation, and Vulnerability' . IPCC Working Group II Contribution to AR5. WVR Moss, 46.

Mubaya, C. P., \& Mafongoya, P. (2017). The role of institutions in managing local level climate change adaptation in semi-arid Zimbabwe. Climate Risk Management, 16, 93-105. https://doi.org/10.1016/j.crm.2017.03.003

Ndreu, A. (2016). The definition and importance of local governance. Social and Natural Sciences Journal, 10 (1), 5-8. https://dx.doi.org/10.12955/snsj. v10i1.730

North, D.C. (1991). Institutions. Journal of Economic Perspectives 5, (1) (Winter 1991), 97-112. https://edisciplinas.usp.br/pluginfile.php/1695541/mod_resource/content/1/North\%20\%281991\%29.pdf 
Nugent, P. (1996). An abandoned project? The nuances of chieftaincy, development and history in Ghana's Volta region. The Journal of Legal Pluralism and Unofficial Law, 28(37-38), 203-225. https://commissionon-legal-pluralism.com/volumes/37-38/nugent-art.pdf

Nunkoo, R. (2015). Tourism development and trust in local government. Tourism Management, 46, 623-634. https://doi:10.1016/j.tourman.2014.08.016

Odetei, I. (2003). Chieftaincy politics in Ghana: Historical dimensions. In O. Vaughan (Ed.), Indigenous political structures and governance in Africa (pp. 322-345). Ibadan: Sefer Books Ltd.

Oladipo, E. (2010). Towards enhancing the adaptive capacity of Nigeria: A review of the country's state of preparedness for climate change adaptation. Henrich Boll Foundation, Nigeria. https://ng.boell.org/sites/default/files/uploads/2013/10/nigeria_prof_oladipo_final_cga_study.pdf

Osei, K. (2002). A Handbook on Asante Culture. Kumasi. Cita Press Ltd.

Rathbone, R. (2000). Nkrumah and the Chiefs: The politics of Chieftaincy in Ghana 1951-60. Ohio: Ohio University Press.

Republic of Ghana (2016). Local Governance Act, 2016 (Act 936) with Amendment (Act 940). Accra: Assembly Press.

Republic of Ghana. (1992). Constitution of the Fourth Republic of Ghana. Accra: Assembly Press.

Roggero, M. (2015). Adapting institutions: exploring climate adaptation through institutional economics and set relations. Ecological Economics, 118, 114-122.http://www.sciencedirect.com/science/article/pii/S0921800915003134

Samuelson, P.A., \& Nordhaus, W.D. (1992) Economics. New York: McGraw-Hall, Inc.

Satterthwaite, D., Archer, D., Colenbrander, S., Dodman, D., Hardoy, J., Mitlin, D., \& Patel, S. (2020). Building resilience to climate change in informal settlements. One Earth, 2(2), 143-156. https://doi.org/10.1016/j.oneear.2020.02.002

Seini, W. A. (2006). The Role of Traditional Authorities in Rural Development. In I.K. Odotei, \& A.K. Awedoba (Eds.), Chieftaincy in Ghana: Culture, Governance and Development (pp. 547-564). Accra: Sub-Saharan Publishers.

Sikander, T. (2016). A Theoretical Framework of Local Government. International Journal of Humanities and Social Sciences, 5(6), 171-176.http://ijhssnet.com/journals/Vol_5_No_6_1_June_2015/19.pdf

Sklar, R.L. (2003). The premise of mixed government in African Political Studies. In O. Vaughan (Ed.), Indigenous Political structures and Governance in Africa (pp. 3-25). Ibadan: Sefer Books Ltd.

Taabazuing, J., Armah, F., Dixon, J., \& Luginaah, I. (2012). The Relationship between Traditional Authorities and Decentralized Structures in Ghana: Conflicting Roles or a Struggle for Power and Legitimacy. Intemational Joumal of Development and Conflict, 2(3), 1-25. https://doi: 10.1142/S2010269012500172

Theesfeld, I., Schleyer, C., Hagedorn, K., Callois, J. M., Aznar, O., \& Olsson, J. A. (2010). The institutional dimension in policy assessment. In Environmental and Agricultural Modelling (pp. 37-59). Springer, Dordrecht. https:// doi:10.4337/9781849802925.00009

UNFCCC (2015). Adoption of the Paris Agreement. Conference of Parties, $21^{\text {st }}$ Session. Paris. https://unfccc.int/resource/docs/2015/cop21/eng/l09r01.pdf

UNFCCC (2006). United Nation Framework Convention on Climate Change Hand Book [ONLINE]. http://unfccc.int/resource/docs/publications/handbook.pdf

Van der Geest, K., \& Warner, K. (2020). Loss and damage in the IPCC Fifth Assessment Report (Working Group II): a text-mining analysis. Climate Policy, 20 (6), 729-742.https://doi.org/10.1080/14693062.2019.1704678 